\title{
STRATEGI PEMASARAN USAHA KERUPUK LEPIT DI DESA DARMACAANG KECAMATAN CIKONENG KABUPATEN CIAMIS
}

\author{
MARKETING STRATEGY FOR LEPIT CRACKERS \\ IN DARMACAANG VILLAGE, CIKONENG DISTRICT, CIAMIS REGENCY
}

\author{
IMA SITI AMALIA ${ }^{1 *}$, DINI ROCHDIANI ${ }^{2}$, BUDI SETIA ${ }^{1}$ \\ ${ }^{1}$ Fakultas Pertanian, Universitas Galuh \\ ${ }^{2}$ Fakultas Pertanian, Universitas Padjadjaran \\ *E-mail: imaamalia11@ gmail.com
}

\begin{abstract}
ABSTRAK
Penelitian ini bertujuan untuk 1) mengidentifikasi kekuatan, kelemahan, peluang dan ancaman usaha kerupuk lepit di Desa Darmacaang Kecamatan Cikoneng Kabupaten Ciamis, 2) merumuskan strategi pemasaran usaha kerupuk lepit di Desa Darmacaang Kecamatan Cikoneng Kabupaten Ciamis. Metode penelitian yang digunakan adalah studi kasus. Data yang dikumpulkan bersumber dari data primer dan data sekunder. Data primer dilakukan dengan cara observasi lapangan dan wawancara dengan pengrajin kerupuk lepit sebagai narasumber. Data sekunder diperoleh dari instansi terkait dan informasi dari berbagai literatur yang berhubungan dengan penelitian ini. Penarikan sampel dalam penelitian ini dilakukan secara purposive sampling yaitu penentuan sampel dengan tujuan tertentu. Hasil penelitian menunjukan bahwa : 1) Berdasarkan faktor internal dan faktor ekternal, kekuatan dalam pemasaran kerupuk lepit di Desa Darmacaang Kecamatan Cikoneng Kabupaten Ciamis meliputi produk tahan lama, cita rasa produk yang khas, tidak menggunakan bahan pengawet, harga terjangkau. Sedangkan kelemahannya yaitu tidak adanya variasi produk, produk setengah jadi, tidak memiliki label produk, pengemasan produk sederhana, promosi masih kurang, permodalan masih terbatas. Peluang yang meliputi pangsa pasar luas, permintaan meningkat, memiliki konsumen tetap, tersedia cukup tenaga kerja. Ancaman yang meliputi adanya pesaing dari industri sejenis, harga bahan baku naik, cuaca dan iklim. 2) Untuk strategi pemasaran, maka direkomendasikan usaha kerupuk lepit di Desa Darmacaang Kecamatan Cikoneng Kabupaten Ciamis adalah melakukan diversifikasi produk agar dapat bersaing di pasar, hal ini mengingat banyak bermunculan industri yang membuat produk sejenis.
\end{abstract}

Kata Kunci : Strategi, Pemasaran, Kerupuk Lepit.

\begin{abstract}
This study aims to determine : 1) Identifying the strengths, weaknesses, opportunities and threats of the lepit cracker business in Darmacaang Village, Cikoneng District, Ciamis Regency. 2) Formulating a business marketing strategy for lepit crackers in Darmacaang Village, Cikoneng District, Ciamis Regency.The research method used case study. The data collected comes from primary data and secondary data. Primary data was carried out by means of field observations and interviews with lepit cracker craftsmen as sources. Secondary data were obtained from related agencies and information from various literatures related to this study. Sampling in this study was carried out by purposive sampling, namely determining the sample with a specific goal.The results showed that:1) Based on internal and external factors, the strength in the marketing of lepit crackers in Darmacaang Village, Cikoneng District, Ciamis Regency includes durable products, distinctive taste of the product, no preservatives, affordable prices. While the weaknesses are the absence of product variations, semifinished products, no product labels, simple product packaging, lack of promotion, limited capital. Opportunities that include a wide market share, increasing demand, having regular customers, sufficient labor. Threats include competitors from similar industries, rising raw material prices, weather and climate.2) For the marketing strategy, it is recommended that the lepit cracker business
\end{abstract}


in Darmacaang Village, Cikoneng District, Ciamis Regency is to diversify the product so that it can compete in the market, this is because there are many industries that make similar products.

Keywords : Strategy, Marketing, Lepit Crackers.

\section{PENDAHULUAN}

Sektor pertanian di Indonesia memiliki banyak peluang dan mempunyai prospek yang sangat besar. Masa sekarang sektor industri lebih diutamakan, salah satu sektor industri yang banyak bergerak disektor industri pengolahan pangan atau yang lebih dikenal dengan agroindustri. Pengembangan agroindustri merupakan salah satu cara sebagai pembangunan di sektor pertanian, yang dimana sektor pertanian mempunyai peranan penting dalam pertumbuhan ekonomi suatu negara terutama bagi negara agraris seperti Indonesia.

Menurut Udayana (2011), agroindustri adalah bagian (subsistem) agribisnis yang memproses dan mentrasformasikan bahan-bahan hasil pertanian menjadi barang setengah jadi yang langsung dapat dikonsumsi, agroindustri merupakan sub sektor yang luas meliputi industri hulu sektor pertanian sampai dengan industri hilir.

Salah satu industri yang ada di Desa Darmacaang Kecamatan Cikoneng Kabupaten Ciamis adalah industri kerupuk lepit. Kerupuk lepit adalah kerupuk yang terbuat dari bahan baku utama campuran tepung terigu dengan tepung tapioka. Dinamakan kerupuk lepit karena proses pembuatannya setelah dicetak bulat lalu dilipatkan menjadi bentuk setengah lingkaran. Terdapat 21 usaha kerupuk lepit di Desa Darmacaang, untuk lebih jelasnya dapat dilihat pada Tabel 1 . 
Tabel 1. Data Kegiatan Usaha Kerupuk Lepit di Desa Darmacaang

Tahun 2020

\begin{tabular}{lllcl}
\hline No & Nama Pemilik & \multicolumn{1}{c}{ Alamat } & $\begin{array}{c}\text { Jumlah } \\
\text { Tenaga } \\
\text { Kerja } \\
\text { (orang) }\end{array}$ & $\begin{array}{c}\text { Berizin / } \\
\text { Tidak Berizin }\end{array}$ \\
\hline 1 & Koko Zulkarim & Dusun Sorok Rt.21 Rw.02 & 10 & Berizin \\
2 & Ujang Deni & Dusun Sorok Rt.03 Rw.02 & 6 & Tidak Berizin \\
3 & Nurfalah & Dusun Sorok Rt.03 Rw.02 & 5 & Tidak Berizin \\
4 & Arif & Dusun Sorok Rt.03 Rw.02 & 5 & Tidak Berizin \\
5 & Lomri & Dusun Sorok Rt.03 Rw.02 & 5 & Tidak Berizin \\
6 & Ade Awat & Dusun Sorok Rt.21 Rw.02 & 8 & Tidak Berizin \\
7 & Ujang Bahtiar & Dusun Sorok Rt.21 Rw.02 & 7 & Tidak Berizin \\
8 & Mumu Muhtarom & Dusun Sorok Rt.01 Rw.01 & 7 & Tidak Berizin \\
9 & Ara Widara & Dusun Sorok Rt.01 Rw.01 & 10 & Tidak Berizin \\
10 & Yeti & Dusun Sorok Rt.01 Rw.01 & 7 & Tidak Berizin \\
11 & Hilman & Dusun Sorok Rt.02 Rw.01 & 5 & Tidak Berizin \\
12 & Mamat & Dusun Sorok Rt.02 Rw.01 & 5 & Tidak Berizin \\
13 & Musa & Dusun Sorok Rt.26 Rw.01 & 6 & Tidak Berizin \\
14 & Yana & Dusun Sorok Rt.02 Rw.01 & 6 & Tidak Berizin \\
15 & Iim Abdul Rohim & Dusun Sorok Rt.02 Rw.01 & 5 & Tidak Berizin \\
16 & Aan Anwar & Dusun Sorok Rt.01 Rw.01 & 7 & Tidak Berizin \\
17 & Gaos & Dusun Sorok Rt.01 Rw.01 & 6 & Tidak Berizin \\
18 & Jejen & Dusun Sorok Rt.02 Rw.01 & 6 & Tidak Berizin \\
19 & Memed & Dusun Sorok Rt.02 Rw.01 & 6 & Tidak Berizin \\
20 & Aji & Dusun Sorok Rt.05 Rw.06 & 5 & Tidak Berizin \\
21 & Aim / Yeti & Dusun Desa Rt.09 Rw.07 & 5 & Tidak Berizin \\
\hline Suman & Pematan & &
\end{tabular}

Sumber: Pemerintah Desa Darmacaang, 2019

Berdasarkan Tabel 1. dari 21 pengrajin kerupuk lepit di Desa Darmacaang hanya terdapat 1 pengrajin kerupuk lepit yang sudah memiliki izin usaha, yaitu Bapak Koko Zulkarim. Dalam menjalankan usaha kerupuk lepit tersebut banyak kendala yang dihadapi oleh pengusaha kerupuk lepit, dari mulai permodalan yang terbatas, tidak mempunyai label produk dan pemasaran, sehingga beberapa diantaranya hanya berproduksi apabila hanya ada pesanan.
Setiap usaha yang bergerak di bidang produk atau jasa, bertujuan untuk tetap bertahan hidup dan berkembang. Agar agroindustri kerupuk lepit tersebut dapat bertahan pada usahanya tentu membutuhkan peningkatan kualitas internal perusahaan dan menyesuaikan dengan perubahan lingkungan industri eksternalnya. Hal ini berkaitan dengan kemampuan perusahaan untuk dapat menjaga hubungan tawar menawar dengan para konsumen. Perumusan strategi yang sesuai dengan kemampuan perusahaan 
agar dapat terus berkembang dalam dunia pemasaran agroindustri perlu dilakukan, agar perusahaan dapat terus menjaga kesinambungan usahanya. Strategi pemasaran kerupuk lepit harus di sesuaikan dengan karakteristik dan permasalahan yang ada di agroindustri tersebut. Strategi pemasaran akan berpengaruh dalam menjaga daya saing dan mengatasi masalah-masalah yang ada pada usaha kerupuk lepit.

Pemasaran merupakan suatu kegiatan untuk menyampaikan barang dan jasa dari produsen kepada konsumen. Proses ini merupakan suatu alur yang melibatkan lembaga-lembaga tata niaga seperti agen, pengumpul, pedagang, pedagang besar, pedagang pengecer serta industri pengolahan dan sebagainya. Dalam melakukan pemasaran, pelaku usaha kerupuk lepit harus memilih pasar sasaran guna mendapatkan, menjaga dan menumbuhkan minat pelanggan dengan menciptakan, menyerahkan dan mengkomunikasikan nilai pelanggan produk kerupuk lepit sehingga tercapai target pemasaran.

Strategi yang harus diterapkan adalah menggunakan kekuatan untuk memanfaatkan peluang yang ada. Kekuatan-kekuatan tersebut agar dapat mengatasi ancaman-ancaman pada usaha kerupuk lepit. Dalam pelaksanaannya, strategi tersebut dilakukan dengan meningkatkan kualitas dan kuantitas produk serta meningkatkan daya tahan produk.

Berdasarkan hal tersebut pentik untuk melakukan penelitian yang berkaitan dengan Strategi Pemasaran Kerupuk Lepit di Desa Darmacaaang Kecamatan Cikoneng Kabupaten Ciamis.

\section{Identifikasi Masalah}

Berdasarkan latar belakang masalah yang telah dikemukakan, maka rumusan masalah dalam penelitian ini sebagai berikut :

1. Bagaimana kekuatan, kelemahan, peluang dan ancaman dalam pemasaran usaha kerupuk lepit di Desa Darmacaang Kecamatan Cikoneng Kabupaten Ciamis ?

2. Bagaimana strategi pemasaran usaha kerupuk lepit di Desa Darmacaang Kecamatan Cikoneng Kabupaten Ciamis?

\section{Tujuan Penelitian}

Berdasarkan identifikasi masalah penelitian di atas maka tujuan dari penelitian ini adalah untuk :

1. Mengidentifikasi kekuatan, kelemahan, peluang dan ancaman usaha kerupuk lepit di Desa 
Darmacaang Kecamatan Cikoneng Kabupaten Ciamis .

2. Merumuskan strategi pemasaran usaha kerupuk lepit di Desa Darmacaang Kecamatan Cikoneng Kabupaten Ciamis.

\section{METODE PENELITIAN}

Metode penelitian yang digunakan dalam penelitian ini adalah studi kasus pada pengusaha kerupuk lepit di Desa Darmacaang. Menurut Nazir (2011), studi kasus merupakan suatu penelitian yang bersifat mendalam mengenai suatu karakteristrik tertentu dari objek penelitian.

Data yang digunakan dalam penelitian terdiri dari data primer dan data sekunder, untuk menunjang kelengkapan pembahasan dalam penulisan ini, penulis memperoleh data yang bersumber dari :

1. Data primer

Data primer merupakan data yang diperoleh secara langsung dari perusahan kerupuk lepit berupa hasil observasi langsung dengan melihat dan mengamati situasi perusahaan dan perolehan dokumen perusahaan serta wawancara pada pemilik usaha maupun pada pekerja yang bersangkutan atau responden sebagai narasumber.

2. Data sekunder
Data sekunder merupakan data yang tidak langsung, yang diperoleh dari dokumen-dokumen. Dalam hal ini bersumber dari penelitian yang meliputi buku-buku bacaan yang berkaitan dengan judul penetitian dari penelitian-penelitian sebelumnya, studi pustaka, literatur dari instansi yang terkait, jurnal dan artikel.

Analisis yang digunakan dalam penelitian ini yaitu menggunakan Matriks SWOT dan Matriks Internal Eksternal dari hasil yang ada kemudian dapat ditentukan pengambilan keputusan yang tepat. Suatu penelitian menunjukan bahwa kinerja penjualan hasil dari strategi pemasaran dapat ditentukan oleh kombinasi faktor internal dan faktor eksternal. Dimana kedua faktor tersebut harus melalui pertimbangan analisis SWOT. Menurut Rangkuti (2015), analisis SWOT merupakan analisis yang digunakan untuk memperoleh formulasi strategi yang tepat dari hasil perbandingan antara faktor internal dan faktor eksternal.

Matriks SWOT merupakan alat untuk mencocokan untuk manajer dalam mengembangkan empat tipe strategi yaitu, strategi SO (kekuatan - peluang), strategi WO (kelemahan - peluang), strategi ST 
(kekuatan - ancaman) dan strategi WT (kelemahan - ancaman). Matriks SWOT menggambarkan dengan jelas bagaimana peluang dan ancaman dapat disesuaikan dengan kekuatan dan kelemahan.

Menurut Rangkuti (2006), diagram analisis SWOT adalah diagram yang menunjukan posisi suatu usaha berdasarkan dari hasil analisis faktor internal dan faktor eksternal suatu usaha. Untuk lebih jelas dapat dilihat pada diagram sebagai berikut :

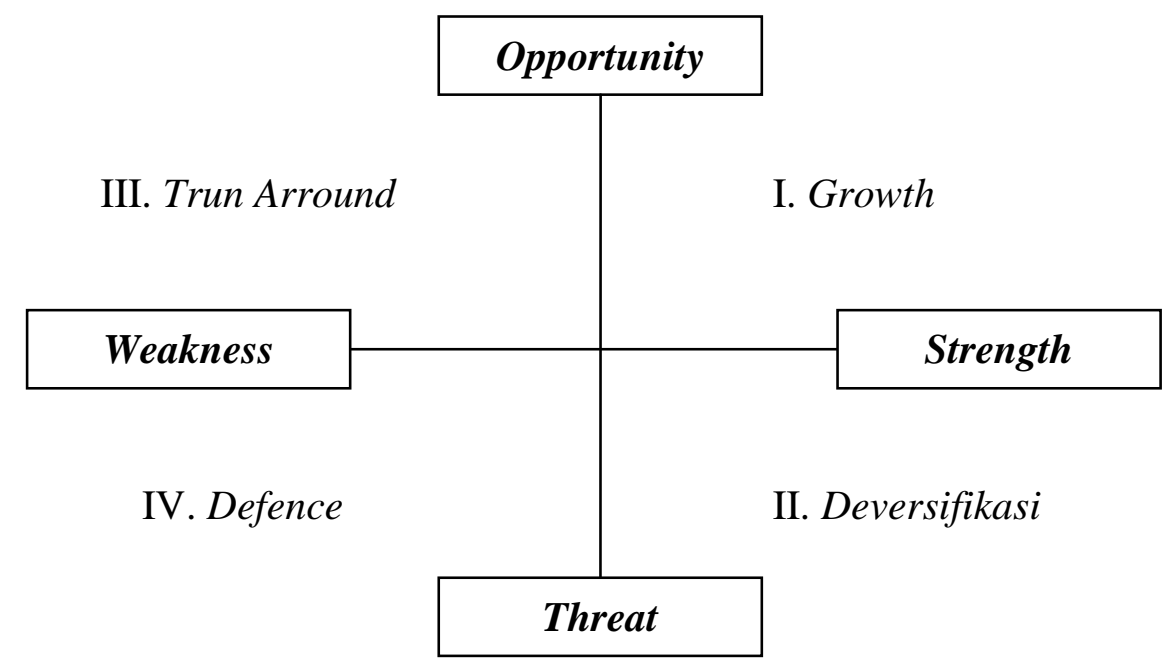

Gambar 1. Diagram SWOT

Keterangan :

a. Kuadran I merupakan situasi yang sangat menguntungkan, dimana perusahaan memiliki peluang dan kekuatan sehingga dapat mengoptimalkan peluang yang ada. Dalam kondisi ini maka strategi yang harus diterapkan adalah mendukung kebijakan pertumbuhan yang agresif (Growth Oriented Strategy). b. Kuadran II dalam situasi ini meskipun menghadapi banyak ancaman, perusahaan masih memiliki kekuatan dari segi internal. Dalam keadaan ini maka strategi yang harus diterapkan adalah menggunakan kekuatan untuk mengoptimalkan peluang jangka panjang dengan cara strategi diversifikasi (produk / pasar). 
c. Kuadran III merupakan situasi peluang pasar yang lebih besar (Turn dimana perusahaan mendapat Arround Strategy).

peluang pasar yang bersar, tetapi

d. Kuadran IV merupakan situasi yang disisi lain perusahaan mengalami kendala atau kelemahan internal. Fokus strategi perusahaan adalah meminimalkan masalah internal perusahaan sehingga mendapat sangat tidak menguntungkan untuk perusahaan, yang dimana perusahaan tersebut menghadapi berbagai ancaman dan kelemahan internal. Maka perusahaan harus mencari strategi bertahan (Defensif Strategy).

\section{Tabel 2. Matriks Faktor Strategi Internal}

\begin{tabular}{llll}
\hline \multicolumn{1}{c}{ Faktor Internal } & Bobot & Nilai & $\begin{array}{c}\text { Bobot } x \\
\text { Nilai }\end{array}$ \\
A. $\quad \begin{array}{l}\text { KEKUATAN } \\
\text { Faktor-faktor yang berasal dari dalam } \\
\text { industri yang merupakan keunggulan } \\
\text { bagi pemasaran agroindustri tersebut. }\end{array}$ & & \\
B. $\quad \begin{array}{l}\text { KELEMAHAN } \\
\text { Faktor-faktor yang berasal dari } \\
\text { dalam industri yang merupakan } \\
\text { kekurangan atau keterbatasan bagi } \\
\text { pemasaran agroindustri tersebut. }\end{array}$ & \\
\hline
\end{tabular}

\section{Total}

Tabel 3. Matriks Faktor Strategi Eksternal

\begin{tabular}{|c|c|c|c|c|}
\hline & Faktor Eksternal & Bobot & Nilai & $\begin{array}{c}\text { Bobot } \times \\
\text { Nilai }\end{array}$ \\
\hline C. & $\begin{array}{l}\text { PELUANG } \\
\text { Faktor-faktor yang berasal dari luar } \\
\text { industri dan bersifat menguntungkan } \\
\text { bagi pemasaran agroindusrti } \\
\text { tersebut. }\end{array}$ & & & \\
\hline D. & $\begin{array}{l}\text { ANCAMAN } \\
\text { Faktor-faktor yang berasal dari luar } \\
\text { industri dan bersifat mengganggu } \\
\text { bagi pemasaran agroindustri } \\
\text { tersebut. }\end{array}$ & & & \\
\hline
\end{tabular}

\section{Total}


Menurut Rangkuti (2009), penentuan matriks faktor strategi eksternal meliputi sebagai berikut :

1. Faktor eksternal adalah faktor-faktor yang menjadi peluang dan ancaman.

2. Bobot dari masing-masing faktor tersebut dengan skala mulai dari 1,0 (paling penting) sampai 0,0 (tidak penting), berdasarkan pengaruh faktor-faktor tersebut terhadap posisi strategis. (Jumlah semua bobot tersebut tidak boleh melebihi skor total 1,00$)$.

3. Nilai untuk masing-masing faktor dengan memberikan skala mulai dari
4 (outstanding) sampai dengan 1 (poor), berdasarkan pengaruh faktor terhadap kondisi tersebut. Variabel yang bersifat positif atau peluang diberi nilai 1 sampai dengan 4 (sangat baik), sedangkan variabel yang bersifat negatif kebalikannya.

4. Bobot pada kolom 2 dengan nilai pada kolom 3 dikalikan, untuk memperoleh pembobotan pada kolom 4.

5. Jumlah total yang merupakan hasil penjumlahan dari skor pembobotan pada kolom 4.

Tabel 5. Matriks SWOT

\begin{tabular}{|l|l|l|}
\hline \multicolumn{1}{|c|}{ IFAS } & \multicolumn{1}{|c|}{ Kekuatan (Strength) } & \multicolumn{1}{c|}{ Kelemahan (Weakness) } \\
\hline $\begin{array}{l}\text { Peluang } \\
\text { (Opportunity) }\end{array}$ & $\begin{array}{l}\text { Strategi S-O } \\
\text { Membuat strategi dengan } \\
\text { menggunakan kekuatan untuk } \\
\text { mengoptimalkan peluang. }\end{array}$ & $\begin{array}{l}\text { Membuat strategi yang } \\
\text { memanfaatkan peluang untuk } \\
\text { mengatasi kelemahan. }\end{array}$ \\
\hline $\begin{array}{l}\text { Ancaman } \\
\text { (Threats) }\end{array}$ & $\begin{array}{l}\text { Strategi S-T } \\
\text { Membuat strategi dengan } \\
\text { menggunakan kekuatan untuk } \\
\text { menghindari dan mengatasi } \\
\text { ancaman. }\end{array}$ & $\begin{array}{l}\text { Membuat strategi yang } \\
\text { meminimalkan kelemahan dan } \\
\text { mengatasi ancaman. }\end{array}$ \\
\hline
\end{tabular}

Berikut ini adalah keterangan dari matriks SWOT diatas :

1. Strategi S-O (Strength -
Opportunity)

Strategi ini dibuat berdasarkan jalan pikiran perusahaan, yaitu dengan memanfaatkan seluruh kekuatan 
untuk mendapatkan peluang yang sebesar-besarnya.

2. Strategi S-T (Strength-Threats)

Strategi dalam menggunakan kekuatan yang dimiliki perusahaan untuk mengatasi ancaman.

3. Strategi W-O (Weakness Opportunity)

Strategi ini diterapkan berdasarkan pemanfaatan peluang yang ada dengan cara meminimalkan kelemahan yang ada.

4. Strategi W-T (Weakness - Threats) Strategi ini berdasarkan kegiatan yang bersifat defensif dan berusaha meminimalkan kelemahan yang dimiliki perusahaan serta menghindari ancaman.

Analisis SWOT merupakan identifikasi berbagai faktor secara sistematis untuk merumuskan strategi, analisis ini dapat memaksimalkan kekuatan (strength) dan peluang (opportunity), dengan secara bersamaan dapat meminimalkan kelemahan (weakness) dan ancaman (thtreats).

\section{HASIL DAN PEMBAHASAN}

Berdasarkan hasil penelitian pada pengrajin kerupuk lepit di Desa Darmacang diperoleh faktor internal dan faktor eksternal. Faktor internal dan faktor eksternal tersebut antara lain :

1. Faktor Internal

Faktor internal yang berkaitan dalam strategi pemasaran kerupuk lepit

di Desa Darmacaang diantaranya, yaitu :

a. Kekuatan (Strengths)

1) Produk Tahan Lama

Daya simpan atau ketahanan produk merupakan salah satu indikator dalam penentuan kualitas suatu produk. Produk kerupuk lepit di Desa Darmacaang Kecamatan Cikoneng Kabupaten Ciamis memiliki daya tahan yang lama. Hal ini disebabkan karena proses penjemuran dilakukan dengan sangat baik sehingga kualitas produk tinggi. Daya simpan produk kerupuk lepit yang berupa babangi atau produk setengah jadi dapat bertahan hingga 3 bulan lamanya.

2) Cita Rasa Produk yang Khas

Cita rasa merupakan suatu cara pemilihan makanan yang dibedakan dari rasa makanan tersebut yang meliputi tekstur, aroma dan rasa. Apabila suatu produk memiliki cita rasa yang khas, produk tersebut akan mudah dikenali dan lebih memudahkan pada saat dipasarkan. 
3) Tidak menggunakan Bahan Pengawet

Kerupuk lepit Bapak Koko Zulkarim di Desa Darmacaang tidak menngunakan bahan pengawet, namun meskipun tidak menggunakan bahan pengawet produk yang dihasilkan tetap tahan lama karena proses pengolahan dan pengeringannya yang sangat baik. Hal ini sangat berpengaruh terhadap permintaan kerupuk lepit. Kerupuk lepit tidak menggunakan pengawet, sehingga mengurangi risiko bahaya dari pengawet sehinnga konsumen lebih aman dalam mengkonsumsi produk kerupuk lepit tersebut. Hal ini menjadi keunggulan usaha kerupuk lepit di Desa Darmacaang.

4) Harga Terjangkau Harga kerupuk lepit Bapak Koko Zulkarim di Desa Darmacaang lebih murah dibanding dengan harga kerupuk lepit pesaing yaitu seharga Rp.125,- per biji. Harga kerupuk lepit Desa Darmacaang yang murah dan terjangkau menjadi salah satu kekuatan yang dimiliki perusahaan.

b. Kelemahan (Weakness)

1) Tidak Adanya Variasi Produk

Variasi produk atau keragaman jenis produk bukanlah hal yang baru dalam dunia pemasaran, strategi ini digunakan oleh praktisi-praktisi pemasaran dalam aktivitas peluncuran produknya. Variasi produk adalah hal penting yang harus diperhatikan oleh perusahaan untuk meningkatkan kinerja produk agar tidak kalah bersaing dengan produk yang lain. Adanya variasi produk, menjadikan konsumen memiliki banyak pilihan dan menambah minat konsumen untuk mengkonsumsi produk kerupuk. Namun pada usaha kerupuk lepit di Desa Darmacaang tidak memproduksi produk yang bervariasi.

2) Produk Setengah Jadi

Kerupuk lepit di Desa Darmacaang hanya memproduksi produk setengah jadi yang berupa babangi. Setelah kerupuk kering dijemur, kerupuk langsung dikemas pada karung dan dipasarkan ke pengusaha atau pabrik penggorengan kerupuk dan atau dijual eceran untuk konsumsi rumah tangga.

3) Tidak memiliki Label Produk

Label merupakan identitas dari suatu produk. Peranan label sangat penting karena label memudahkan konsumen dalam pemilihan produk yang diperlukannya selain itu label 
menambah nilai tambah pada suatu produk. Produk kerupuk lepit di Desa Darmacaang tidak menggunakan label dalam pengemasannya.

4) Pengemasan Produk Sederhana Kemasan produk yang menarik menjadi daya tarik bagi konsumen untuk membeli sebuah produk dan menjadi nilai tambah bagi produk tersebut. Namun, produk kerupuk lepit di Desa Darmacaang hanya menggunakan karung sebagai kemasan ketika di pasarkan.

5) Promosi masih kurang

Promosi merupakan upaya untuk menawarkan produk atau jasa dengan tujuan menarik konsumen untuk membeli atau mengkonsumsinya. Dengan adanya promosi, produsen mengharapkan kenaikan angka dalam penjualannya. Namun, pihak kerupuk lepit tidak melakukan promosi hal ini dikarenakan kurangnya dana atau modal yang dimiliki sehingga hal ini menjadi kendala dalam melakukan promosi. Kurangnya promosi menyebabkan produk sulit dikenal secara luas hanya konsumen tetap yang mengetahuinya.

6) Permodalan yang masih Terbatas
Modal yang terbatas menjadi kendala bagi perusahaan kerupuk lepit Desa Darmacaang. Perusahaan hanya mempunyai modal apabila konsumen besar dari kota besar membayar diawal.

2. Faktor Eksternal

Adapun faktor eksternal yang diidentifikasi pada usaha kerupuk lepit di Desa Darmacaang Kecamatan Cikoneng Kabupaten Ciamis, yaitu :

a. Peluang (Opportunity)

1) Pangsa Pasar Luas

Kerupuk lepit bukan hanya diminati oleh masyarakat setempat tetapi banyak diminati oleh masyarakat kota besar, hal itu terbukti karena perusahaan selalu mendapat pesanan kerupuk lepit dari kota-kota besar. Sehingga dapat dikatakan pangsa pasar kerupuk lepit luas, ditambah harga kerupuk lepit yang relatif terjangkau.

2) Permintaan Meningkat

Permintaan adalah sejumlah barang yang diminta pada suatu harga dan waktu tertentu. Jika permintaan meningkat maka member peluang bagi usaha untuk meningkatkan produksi guna memperoleh pendapatan yang meningkat. Demikian juga hal nya dengan usaha 
kerupuk lepit di Desa Darmacaang dalam hal pemasaran. Meningkatnya permintaan terhadap kerupuk lepit dapat dilihat dari produksi yang meningkat. Peningkatan produksi dilakukan untuk memenuhi jumlah permintaan sehingga dapat mencapai sasaran pemasaran. Meningkatnya jumlah permintaan, maka usaha kerupuk lepit di Desa Darmacaang harus semaksimal mungkin untuk memenuhi jumlah permintaan tersebut. Kondisi ini memberi dampak positif untuk usaha kerupuk lepit.

3) Memiliki Konsumen Tetap

Memiliki konsumen atau pembeli yang tetap maka perusahaan tidak akan kesulitan dalam hal pemasaran. Adanya konsumen sebagai pembeli tetap harus dijaga untuk kelangsungan usaha kerupuk lepit dengan cara meningkatkan kualitas kerupuk lepit, hal tersebut dilakukan agar konsumen tidak berpindah ke tempat lain. Kerupuk lepit yang berupa babangi atau produk kerupuk setengah jadi dijual ke pengusaha atau pabrik khusus pengenggorengan kerupuk dan atau dijual eceran untuk konsumsi rumah tangga.

4) Tersedia Cukup Tenaga Kerja
Tersedia SDM yang cukup menjadi kekuatan pada perusahaan, pengolahan kerupuk lepit umumnya dapat dikerjakan oleh siapa saja karena proses produksinya mudah dilakukan.

b. Ancaman (Threat)

1) Adanya Pesaing Dari Industri Sejenis Pesaing adalah perusahaan yang menciptakan atau menghasilkan dan menjual barang dan jasa yang sama atau mirip dengan produk yang ditawarkan. Banyaknya usaha kerupuk lepit di Desa Darmacaang Kecamatan Cikoneng Kabupaten Ciamis menjadi ancaman bagi usaha kerupuk lepit ini. Dalam kondisi ini harus dilakukan strategi yang tepat untuk mengatasi persaingan.

2) Harga Bahan Baku Naik

Bahan baku adalah bahan yang digunakan dalam proses membuat suatu produk dimana bahan tersebut secara menyeluruh tampak pada produk jadinya. Sedangkan biaya bahan baku adalah seluruh biaya yang di gunakan untuk memperoleh sampai dengan bahan siap untuk digunakan yang meliputi harga bahan, biaya angkut, penyimpanan dan lain-lain. Namun jika harga bahan baku tidak stabil, maka akan 
memberi pengaruh yang buruk bagi suatu usaha.

3) Cuaca dan Iklim

Cuaca dan iklim sangat mempengaruhi produktivitas kerupuk lepit. Proses pengeringan kerupuk masih memanfaatkan sinar matahari. Apabila tidak ada panas sinar matahari maka akan menghambat proses pengeringan kerupuk lepit. Dalam hal ini cuaca sangat menentukan kualitas kerupuk lepit.
Setelah faktor internal dan eksternal diidentifikasi, selanjutnya menyusun tabel IFAS (Internal Strategic Factors Analysis Summary) dan EFAS (Eksternal Strategic Factors Analysis Summary), tabel IFAS dan EFAS disusun untuk merumuskan faktor-faktor strategi internal dalam kerangka kekuatan dan kelemahan serta faktor-faktor strategi eksternal dalam kerangka peluang dan ancaman. Untuk lebih jelasnya dapat dilihat pada Tabel 6 . dan Tabel 7.

Tabel 6. IFAS (Internal Strategic Factors Analysis Summary)

\begin{tabular}{|c|c|c|c|}
\hline Faktor Internal & \multirow[t]{2}{*}{ Bobot } & \multirow[t]{2}{*}{ Rating } & \multirow[t]{2}{*}{ Bobot $\times$ Rating } \\
\hline Kekuatan & & & \\
\hline 1. Produk Tahan Lama & 0,15 & 4 & 0,60 \\
\hline $\begin{array}{l}\text { 2. Cita Rasa Produk yang } \\
\text { Khas }\end{array}$ & 0,15 & 3 & 0,45 \\
\hline $\begin{array}{l}\text { 3. Tidak Menggunakan Bahan } \\
\text { Pengawet }\end{array}$ & 0,15 & 3 & 0,45 \\
\hline 4. Harga Terjangkau & 0,10 & 3 & 0,30 \\
\hline \multicolumn{4}{|l|}{ Kelemahan } \\
\hline $\begin{array}{l}\text { 1. Tidak Adanya Variasi } \\
\text { Produk }\end{array}$ & 0,05 & 2 & 0,10 \\
\hline 2. Produk Setengah Jadi & 0,10 & 3 & 0,30 \\
\hline $\begin{array}{l}\text { 3. Tidak Memiliki Label } \\
\text { Produk }\end{array}$ & 0,05 & 2 & 0,10 \\
\hline $\begin{array}{l}\text { 4. Pengemasan Produk } \\
\text { Sederhana }\end{array}$ & 0,10 & 3 & 0,30 \\
\hline 5. Promosi Masih Kurang & 0,05 & 2 & 0,10 \\
\hline $\begin{array}{l}\text { 6. Permodalan yang Masih } \\
\text { terbatas }\end{array}$ & 0,10 & 3 & 0,30 \\
\hline Total & 1,00 & & $\mathbf{3 , 0 0}$ \\
\hline
\end{tabular}

Tabel 7. memperlihatkan bahwa nilai total kekuatan dan kelemahan adalah 3,00 nilai total ini menggambarkan bahwa pengrajin kerupuk lepit memiliki dukungan faktor internal relatif sedang. 
Tabel 7. EFAS (Eksternal Strategic Factors Analysis Summary)

\begin{tabular}{|c|c|c|c|}
\hline Faktor Eksternal & \multirow[t]{2}{*}{ Bobot } & \multirow[t]{2}{*}{ Rating } & \multirow[t]{2}{*}{ Bobot $\times$ Rating } \\
\hline Peluang & & & \\
\hline 1. Pangsa Pasar Luas & 0,15 & 2 & 0,30 \\
\hline 2. Permintaan Meningkat & 0,10 & 3 & 0,30 \\
\hline 3. Memiliki Konsumen Tetap & 0,15 & 3 & 0,45 \\
\hline $\begin{array}{l}\text { 4. Tersedia Cukup Tenaga } \\
\text { Kerja }\end{array}$ & 0,10 & 3 & 0,30 \\
\hline \multicolumn{4}{|l|}{ Ancaman } \\
\hline $\begin{array}{l}\text { 1. Adanya Pesaing dari } \\
\text { Industri Sejenis }\end{array}$ & 0,20 & 4 & 0,80 \\
\hline 2. Harga Bahan Baku Naik & 0,15 & 3 & 0,45 \\
\hline $\begin{array}{l}\text { 3. Cuaca dan Iklim Sangat } \\
\text { Mempengaruhi }\end{array}$ & 0,15 & 3 & 0,45 \\
\hline Total & 1,00 & & 3,05 \\
\hline
\end{tabular}

Tabel 7. menunjukan bahwa nilai total peluang dan ancaman adalah 3,05 nilai total ini menggambarkan bahwa pengrajin kerupuk lepit memiliki dukungan faktor eksternal yang juga sedang.

Berdasarkan dari hasil IFAS dan EFAS, maka dapat diambil tahap-tahap pengambilan keputusan untuk menyusun beberapa strategi yang digambarkan dalam diagram SWOT, sehingga strategi yang muncul dapat dijadikan sebagai acuan dalam memasarkan kerupuk lepit di Desa Darmacaang Kecamatan Cikoneng Kabupaten Ciamis.

Hasil IFAS dan EFAS didapat nilai, sebagai berikut

\begin{tabular}{|c|c|}
\hline Kekuatan (Strength) & 1,8 \\
\hline Kelemahan (Weakness) & 1,2 \\
\hline Peluang (Opportunity) & 1,35 \\
\hline Ancaman (Threat) & 1,7 \\
\hline
\end{tabular}

Untuk membuat diagram maka harus mencari posisi $\mathrm{x}$ dan $\mathrm{y}$ dengan rumus sebagai berikut :

$$
\begin{aligned}
& x=\frac{S-W}{2}=\frac{1,8-1,2}{2}=0,3 \\
& y=\frac{0-T}{2}+\frac{1,35-1,7}{2}=-0,175
\end{aligned}
$$




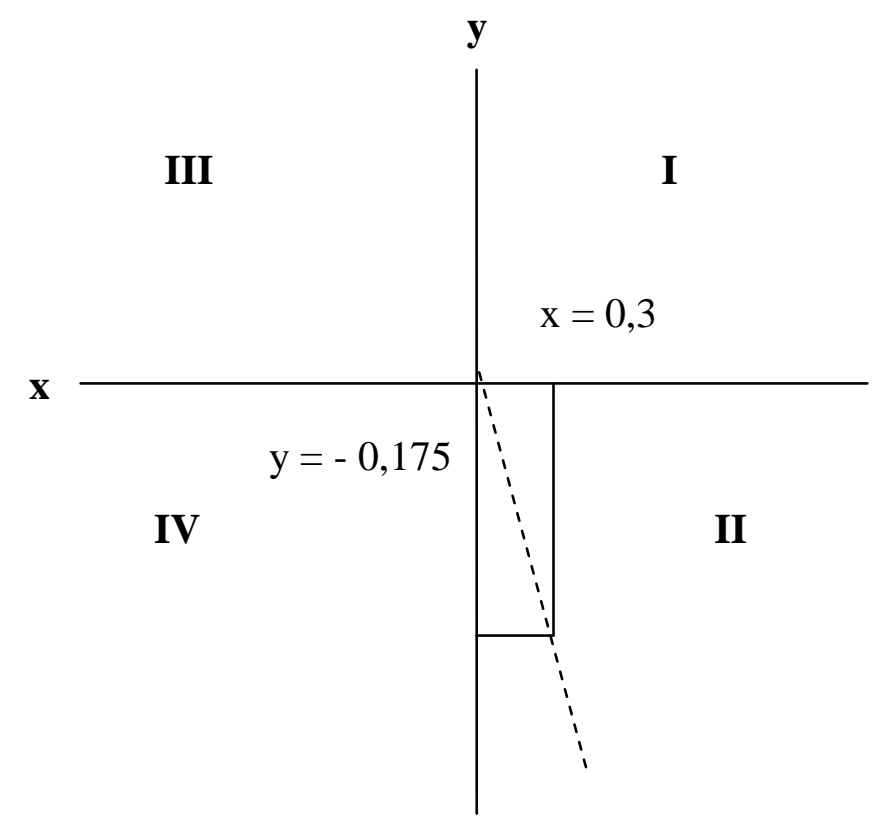

Gambar 3. Diagram SWOT

Hasil analisis diagram SWOT menunjukan bahwa usaha kerupuk lepit di Desa Darmacaang berada pada kuadran II. Posisi ini menandakan sebuah perusahaan yang kuat dan berpeluang, rekomendasi strategi yang diberikan adalah diversifikasi (Rangkuti, 2006). Meskipun mengahadapi berbagai ancaman, usaha kerupuk lepit ini masih memiliki kekuatan dari segi internal. Dalam pelaksanaannya, strategi diversifikasi bisa dilakukan dengan menciptakan variasi atau inovasi produk dangan tetap mempertahankan kualitas produk kerupuk lepit. Hal ini akan menguntungkan untuk usaha kerupuk lepit, dikarenakan permintaan produk meningkat.

\section{Strategi Pemasaran}

Setelah mengidentifikasi faktor internal dan faktor eksternal yang menjadi kekuatan, kelemahan, peluang serta ancaman dalam pemasaran kerupuk lepit di Desa Darmacaang Kecamatan Cikoneng Kabupaten Ciamis selanjutnya penentuan alternatif strategi yang dapat ditentukan dengan menggunakan Matrik SWOT. Menurut Rangkuti (2009) menjelaskan bahwa Matrik SWOT dapat menggambarkan secara jelas bagaimana peluang dan ancaman yang dihadapi perusahaan dapat disesuaikan dengan kekuatan dan kelemahan yang dimiliki oleh perusahaan. Matrik ini dapat 
menghasilkan alternatif strategi, sebagaimana dapat dilihat pada Tabel 8.

Tabel 8. Matrik SWOT

\begin{tabular}{|c|c|c|}
\hline \multirow[t]{2}{*}{ IFAS } & Strength (S) & Weakness (W) \\
\hline & $\begin{array}{l}\text { 1. Produk Tahan Lama } \\
\text { 2. Cita Rasa Produk yang Khas } \\
\text { 3. Tidak Menggunakan Bahan } \\
\text { Pengawet } \\
\text { 4. Harga Terjangkau } \\
\text { 5. Tersedia Cukup Tenaga } \\
\text { Kerja }\end{array}$ & $\begin{array}{l}\text { 1. Tidak Adanya Variasi } \\
\text { Produk } \\
\text { 2. Produk Setengah Jadi } \\
\text { 3. Tidak Memiliki Label } \\
\text { Produk } \\
\text { 4. Pengemasan Produk } \\
\text { Sederhana } \\
\text { 5. Promosi Masih Kurang } \\
\text { 6. Permodalan yang Masih } \\
\text { terbatas }\end{array}$ \\
\hline Opportunity $(\mathbf{O})$ & Strateoi (S_O & $\operatorname{tegi}(\mathbf{W}-O)$ \\
\hline $\begin{array}{l}\text { 1. Pangsa Pasar Luas } \\
\text { 2. Permintaan Meningkat } \\
\text { 3. Memiliki Konsumen } \\
\text { Tetap }\end{array}$ & $\begin{array}{l}\text { 1. Meningkatkan kuantitas } \\
\text { produk sehingga dapat } \\
\text { memenuhi jumlah } \\
\text { permintaan yang } \\
\text { meningkat. } \\
\text { 2. Mempertahankan kualitas } \\
\text { produk dan pengembangan } \\
\text { pemasarannya. } \\
\text { 3. Menjaga konsumen dengan } \\
\text { baik agar menjadi pelanggan } \\
\text { tetap. }\end{array}$ & $\begin{array}{l}\text { 1. Melakukan kegiatan } \\
\text { promosi dengan media } \\
\text { elektronik untuk meraih } \\
\text { kemungkinan akan } \\
\text { bertambahnya konsumen } \\
\text { baru. } \\
\text { 2. Membuat label dan } \\
\text { pengemasan yang menarik } \\
\text { sehingga memiliki daya } \\
\text { tarik terhadap konsumen. } \\
\text { 3. Membuat inovasi atau } \\
\text { variasi pada produk. }\end{array}$ \\
\hline Threat $(\mathrm{T})$ & $\begin{array}{l}\text { Strategi }(\mathrm{S}-\mathrm{T}) \\
\end{array}$ & Strategi $(\mathrm{W}-\mathrm{T})$ \\
\hline $\begin{array}{l}\text { 1. Adanya Pesaing dari } \\
\text { Industri Sejenis } \\
\text { 2. Harga Bahan Baku } \\
\text { Naik } \\
\text { 3. Cuaca dan Iklim } \\
\text { Sangat Mempengaruhi }\end{array}$ & $\begin{array}{l}\text { 1. Menyesuaikan harga } \\
\text { produk dengan harga bahan } \\
\text { baku namun tetap bisa } \\
\text { dijangkau oleh berbagai } \\
\text { kalangan. } \\
\text { 2. Mempertahankan kualitas } \\
\text { produk dan cita rasa agar } \\
\text { mudah dikenali oleh } \\
\text { konsumen walaupun } \\
\text { banyak produk pesaing di } \\
\text { lokasi yang sama. }\end{array}$ & $\begin{array}{l}\text { 1. Menambah permodalan. } \\
\text { 2. Meningkatkan kualitas } \\
\text { SDM untuk } \\
\text { menanggulangi cuaca yang } \\
\text { ekstrim. }\end{array}$ \\
\hline
\end{tabular}

Berdasarkan Tabel 8. maka dapat diperoleh beberapa strategi yang dapat dipertimbangkan, antara lain :

\section{a. Strategi S-O}

Strategi Strength - Opportunity (S-O) atau strategi kekuatan - peluang adalah 
strategi yang disusun dengan cara menggunakan kekuatan untuk menciptakan atau mendapatkan peluang.

Strategi S-O yang dapat dirumuskan adalah :

1. Meningkatkan kuantitas produk sehingga dapat memenuhi jumlah permintaan yang meningkat.

Meningkatkan kuantitas produk penting dilakukan untuk tetap terus memenuhi jumlah permintaan yang meningkat pada produk. Hal ini perlu dilakukan agar pelanggan atau konsumen tidak berpindah ketempat lain.

2. Mempertahankan kualitas produk dan pengembangan pemasarannya. Mempertahankan kualitas sangat penting untuk dapat terus bersaing dan dalam upaya mengembangkan pemasaran. Mempertahankan kualitas produk dapat dilakukan dengan menentukan standarisasi kualitas produk. Pengembangan pasar dilakukan untuk peningkatan volume penjualan dengan menawarkan produk pada konsumen atau pedagang di daerah lain yang potensial, sehingga dapat menjadi salah satu cara untuk memperluas daerah pemasaran.
3. Menjaga konsumen dengan baik agar menjadi pelanggan tetap. Layanan yang baik terhadap konsumen sangatlah penting dalam bermitra selain agar menjadi pelanggan tetap, juga menjadi peluang dalam peluasan pemasaran produk.

\section{b. Strategi W-O}

\section{Strategi Weakness - Opportunity} (W-O) atau strategi kelemahan -peluang adalah strategi yang disusun dengan cara meminimalkan kelemahan yang ada untuk memanfaatkan dan menciptakan peluang.

Strategi W-O yang dapat dirumuskan adalah :

1. Melakukan kegiatan promosi dengan media elektronik untuk meraih kemungkinan akan bertambahnya konsumen baru.

Kegiatan promosi penting dilakukan agar masyarakat luas mengenal suatu produk, pada zaman ini kegiatan promosi mudah dilakukan dengan menggunakan media elektronik atau media sosial. Kegitan promosi ini selain mudah juga tidak memerlukan modal yang besar dan cepat menyebarkan informasi hingga kepenjuru dunia, sehingga lebih efisien. Kondisi ini, lebih membuka peluang untuk bertambahnya konsumen baru dari berbagai daerah. 
2. Membuat label dan pengemasan yang menarik sehingga memiliki daya tarik terhadap konsumen.

Label adalah identitas dari suatu produk, yang dapat memudahkan konsumen mencari produk yang dibutuhkan dan menjadi daya tarik konsumen untuk membeli. Sama halnya dengan pengemasan, pengemasan yang menarik dan rapih membuat pelanggan menjadi tertarik untuk membeli produk tersebut.

3. Membuat inovasi atau variasi pada produk.

Variasi produk menjadi penting dilakukan untuk menambah nilai tambah pada suatu produk. Variasi produk bisa dilakukan dengan menambah pilihan rasa pada produk tersebut, sehingga menambah daya tarik terhadap konsumen untuk membeli.

\section{c. Strategi S-T}

Strategi Strength - Threat (S-T) atau strategi kekuatan - ancaman adalah strategi yang disusun dengan mengoptimalkan kekuatan yang dimiliki untuk mengatasi atau menghindari ancaman.

Strategi S-T yang dapat dirumuskan adalah :
1. Menyesuaikan harga produk dengan harga bahan baku namun tetap bisa dijangkau oleh berbagai kalangan.

Kenaikan harga bahan baku kerap terjadi, maka strategi yang harus dilakukan adalah menyesuaikan harga produk dengan harga bahan baku namun tetap bisa dijangkau oleh semua kalangan.

2. Mempertahankan kualitas produk dan cita rasa agar mudah dikenali oleh konsumen walaupun banyak produk pesaing di lokasi yang sama. Banyaknya pesaing dilokasi yang sama menjadi ancaman, maka dari itu mempertahankan kualitas produk dan cita rasa yang khas atau berbeda dari produk pesaing menjadi keharusan agar konsumen mudah mengenali produk tersebut.

\section{d. Strategi W-T}

Strategi Weakness - Threat (W-T) atau strategi kelemahan - ancaman adalah strategi yang disusun dengan cara meminimalkan kelemahan untuk menghindari ancaman.

Strategi W-T yang dapat dirumuskan adalah :

1. Menambah permodalan.

Menambah permodalan bisa dilakukan untuk memperbaiki 
pengemasan dan label, atau apabila terjadi kenaikan bahan baku.

2. Meningkatkan kualitas SDM untuk menanggulangi cuaca yang ekstrim.

Cuaca memang sulit diprediksikan, cuaca yang ekstrim dapat menurunkan kualitas dan kuantitas produk. Maka dari itu pelu adanya peningkatan kualitas SDM agar pengrajin dapat mengatasi permasalahan akibat cuaca yang ekstrim. SDM yang dibutuhkan adalah yang berusia produktif, karena masih mempunyai kekuatan fisik yang cukup baik dalam bekerja.

\section{KESIMPULAN DAN SARAN}

\section{Kesimpulan}

Berdasarkan hasil penelitian dan pembahasan dapat diambil kesimpulan sebagai berikut :

1) Faktor internal dan faktor ekternal dalam pemasaran kerupuk lepit Bapak Koko Zulkarim di Desa Darmacaang Kecamatan Cikoneng Kabupaten Ciamis yaitu :

a. Kekuatan yang meliputi produk tahan lama, cita rasa produk yang khas, tidak menggunakan bahan pengawet, harga terjangkau.

b. Kelemahan yang meliputi tidak adanya variasi produk, produk setengah jadi, tidak memiliki label produk, pengemasan produk sederhana, promosi masih kurang, permodalan yang masih terbatas.

c. Peluang yang meliputi pangsa pasar luas, permintaan meningkat, memiliki konsumen tetap, tersedia cukup tenaga kerja.

d. Ancaman yang meliputi adanya pesaing dari industri sejenis, harga bahan baku naik, cuaca dan iklim sangat mempengaruhi.

2) Strategi pemasaran yang direkomendasikan usaha kerupuk lepit di Desa Darmacaang Kecamatan Cikoneng Kabupaten Ciamis adalah diversifikasi produk agar dapat bersaing di pasar, hal ini mengingat banyak bermunculan industri yang membuat produk sejenis.

\section{Saran}

Berdasarkan uraian pada pembahasan dan kesimpulan, maka saran dalam penelitian ini yaitu :

1. Perlu melakukan promosi dengan cara membuat promosi melalui media elektronik atau media sosial dengan membangun bisnis online, dengan demikian pemasaran kerupuk lepit bisa menjangkau masyarakat luas. 
2. Membuat label dan pengemasan agar indentitas produk bisa diketahui konsumen, serta konsumen bisa membedakan produk dengan produk yang dimiliki oleh pesaing.

\section{DAFTAR PUSTAKA}

Nazir M, 2011. Metode Penelitian. Ghalia Indonesia, Bogor.

Rangkuti, F, 2009. Analisis SWOT Teknik Membedah Kasus Bisnis. Gramedia Pustaka Utama. Jakarta.

Rangkuti, Freddy. 2006. Analisis SWOT Teknik Membedah Kasus Bisnis. PT. Gramedia Pustaka Utama, Jakarta.

Undayana, I Gusti Bagus. 2011. Peran Agroindustri dalam Pembangunan Pertanian. Singhadwala, edisi 44. 